\title{
Chronic stress augments esophageal inflammation, and alters the expression of transient receptor potential vanilloid 1 and protease-activated receptor 2 in a murine model
}

\author{
WUBULIKASIMU WULAMU ${ }^{1-3}$, MAIMAITI YISIREYILI ${ }^{1,2}$, AIKEBAIER AILI ${ }^{1,2}$, \\ KYOSUKE TAKESHITA ${ }^{4}$, AZIGULI ALIMUJIANG ${ }^{5}$, ALIYEGULI AIPIRE ${ }^{1}$, YILIANG LI ${ }^{2}$, \\ YUAN JIANG ${ }^{2}$, MAIMAITIAILI AIZEZI ${ }^{6}$, ZANLIN LI $^{2}$ and KELIMU ABUDUREYIMU ${ }^{1,2}$ \\ ${ }^{1}$ Research Institute of General and Minimally Invasive Surgery; ${ }^{2}$ Department of Minimally Invasive Surgery, \\ Hernia and Abdominal Wall Surgery, People's Hospital of Xinjiang Uygur Autonomous Region, Urumqi, \\ Xinjiang 830001; ${ }^{3}$ Graduate School of Xinjiang Medical University, Urumqi, Xinjiang 830054, P.R. China; \\ ${ }^{4}$ Department of Cardiology, Nagoya University Graduate School of Medicine, Nagoya, Aichi 460-8550, Japan; \\ Departments of ${ }^{5}$ Obstetrics and Gynecology Clinic, and ${ }^{6}$ Cardiac Surgery, People's Hospital of \\ Xinjiang Uygur Autonomous Region, Urumqi, Xinjiang 830001, P.R. China
}

Received August 8, 2018; Accepted March 7, 2019

DOI: $10.3892 / \mathrm{mmr} .2019 .10192$

\begin{abstract}
Stress is a pivotal factor for inflammation, reactive oxygen species (ROS) production and formation of visceral hypersensitivity $(\mathrm{VH})$ in the process of gastroesophageal reflux disease (GERD). In the present study, the effects of stress on esophageal inflammation, oxidative stress and $\mathrm{VH}$ were investigated in a chronic restraint stress mouse model. C57BL/6J male mice were subjected to 2 weeks of intermittent restraint stress, and histopathological analysis revealed that stress induced esophageal inflammation and fibrosis, while no distinct changes were detected in non-stressed control mice. In addition, increased NADPH oxidase 4 expression was observed in the plasma and esophagus of stressed mice, indicating accumulation of ROS. The expression levels of antioxidants, including Mn-superoxide dismutase (MnSOD), $\mathrm{Cu} / \mathrm{Zn}$-SOD, catalase and glutathione peroxidase, were also analyzed using reverse transcription-quantitative polymerase chain reaction (RT-qPCR). In addition, transient receptor potential vanilloid 1 (TRPV-1) and protease-activated receptor 2 (PAR-2), which are crucial receptors for $\mathrm{VH}$, were measured by immunohistochemistry and RT-qPCR. The results demonstrated that stress markedly reduced antioxidant expression, while it significantly upregulated
\end{abstract}

Correspondence to: Professor Kelimu Abudureyimu, Department of Minimally Invasive Surgery, Hernia and Abdominal Wall Surgery, People's Hospital of Xinjiang Uygur Autonomous Region, 91 Tianchi Road, Tianshan, Urumqi, Xinjiang 830001, P.R. China E-mail:klm6075@163.com

Key words: stress, esophageal inflammation, reactive oxygen species, visceral hypersensitivity
TRPV-1 and PAR-2 expression levels in the mouse esophagus. Finally, 2 weeks of restraint stress significantly increased the esophageal and plasma levels of inflammatory cytokines, including interleukin (IL)-6, IL-8, interferon- $\gamma$ and tumor necrosis factor- $\alpha$. Taken together, the present study results indicated that stress-induced esophageal inflammation and ROS generation involves $\mathrm{VH}$.

\section{Introduction}

With the rapid development of science and technology, as well as strong social competition, the nature of psychological stress has changed significantly (1). Stress is a common risk factor for $75-90 \%$ of diseases, including cardiovascular diseases, associated with the highest morbidity and mortality (2). Accumulating evidence has demonstrated that severe or chronic stress results in an increased risk for physical and psychiatric disorders, which is referred to as stress-associated disease. In stress animal models, accumulation of oxidative stress has been noted (3). Halliwell (4) reported that overproduction of reactive oxygen species (ROS) can damage cellular components and induce functional abnormalities in numerous cell types. Chronic stress modifies the expression of the genes regulating antioxidant system and NADPH oxidase (Nox) (5). Furthermore, Nox has been reported to be a major source of ROS production in different cell types (6), while experiments from rodent models suggested that increased levels of ROS in vitro and in the brain can result in downregulation of various antioxidant enzymes (7).

Stress aggravates typical clinical symptoms, such as heartburn in patients with gastroesophageal reflux disease (GERD), while it also affects visceral sensitivity (8). However, the mechanism underlying visceral hypersensitivity $(\mathrm{VH})$ in functional gastrointestinal disorders is not completely understood. The involvement of stress in $\mathrm{VH}$, specifically in esophageal 
hypersensitivity, has also been investigated. Fass et al (9) reported that GERD patients experienced severe heartburn when exposed to acute auditory stress, while stress caused by disturbed sleep has also been demonstrated to cause similar esophageal hypersensitivity (10). Another study indicated that psychological factors, such as stress, influence $\mathrm{VH}$ in humans (11).

Two main receptors have been reported to contribute to the mechanism underlying esophageal hypersensitivity, namely proteinase-activated receptor 2 (PAR-2) and transient receptor potential channel vanilloid 1 (TRPV-1) $(12,13)$. A previous study revealed that acid exposure can increase the expression of PAR-2 on esophageal epithelial cells (14). The role of PAR-2 in the pathogenesis of GERD has also been assessed. PAR-2 is activated by mast cell tryptase and trypsin throughout the entire gastrointestinal tract under physiologic or pathophysiologic conditions (15). In vitro experiments of esophageal squamous cell lines demonstrated that PAR-2 expression was induced by exposure to acidic and weakly acidic solutions (16), and PAR-2 activation mediated $\mathrm{VH}$ and pain (17). In addition to PAR-2, acid-sensitive receptors, such as TRPV-1, are accountable for one of the important mechanisms that are involved in peripheral esophageal hypersensitivity. A study involving TRPV-1 knockout mice revealed that TRPV-1 is a key receptor that responds to mechanical or acid irritation, as well as thermal stimulation (18). Several studies have also demonstrated the existence of neural fibers with TRPV-1 expression in the esophageal mucosa, as well as increased mRNA and protein expression in the esophageal mucosa of patients with reflux esophagitis and non-erosive reflux disease, suggesting the involvement of TRPV-1 in the mechanism underlying esophageal hypersensitivity $(19,20)$.

Therefore, in the present study, the aim was to determine whether chronic stress evokes esophageal inflammation, ROS production and $\mathrm{VH}$ in a murine model.

\section{Materials and methods}

Experimental animals. In total, 20 male C57BL/6J mice (8-week-old) were obtained from the Animal Center of Xinjiang Medical University (Urumqi, China). Animals were housed (one per cage) under standard conditions of $21-25^{\circ} \mathrm{C}$ and $50 \pm 5 \%$ humidity with a $12 / 12 \mathrm{~h}$ light/dark cycle (lights on at 8:30 a.m.) in a specific-pathogen-free facility in the Research Institute of Uygur Pharmaceutics (Urumqi, China). All mice were provided tap water and standard chow diet ad libitum ( $18 \%$ fat, $24 \%$ protein, $58 \%$ carbohydrates). The study protocol was approved by the Animal Care and Use Committee of the People's Hospital of Xinjiang Uygur Autonomous Region (protocol no. KY201803703; Urumqi, China). The study was completed based on the Guidelines for the Care and Use of Laboratory Animals published by the National Institutes of Health.

Restraint stress protocol. The mice were randomly divided into the control $(n=10)$ and chronic restraint stress groups (CRS, $n=10)$. Each of the control mice were left undisturbed and remained in a single cage, while stressed mice were isolated in individual cages and subjected to immobilization stress for $2 \mathrm{~h}$ per day (6 days per week, between 10:00 a.m. and 12:00 p.m.) over a period of 14 consecutive days, as described in detail previously $(21,22)$. Body weight and food intake were monitored every 2 days during the stress period.

Sample collection. In the morning following the last restraint stress, all mice underwent a 16 to 18 -h fasting period, anesthetized by intraperitoneal injection of sodium pentobarbital $(150 \mathrm{mg} / \mathrm{kg})$ and then euthanized. Subsequent to euthanasia, blood samples were collected from the inferior vena cava, and stored at $-80^{\circ} \mathrm{C}$. Esophageal samples were also collected under aseptic conditions and stored in RNase-free tubes at $-80^{\circ} \mathrm{C}$ for extraction of total RNA, analysis of biological marker expression levels and histopathological examination.

Histopathological assay. The esophageal tissues of all mice were excised, weighed, fixed with $10 \%$ formalin, dehydrated at room temperature by ethanol series and then embedded in paraffin. Next, tissues were cut into $5-\mu \mathrm{m}$ sections and stained with hematoxylin and eosin (H\&E) or Masson's trichrome (MT) for the evaluation of esophageal inflammation and fibrosis, respectively. Images of $\mathrm{H} \& \mathrm{E}$ and $\mathrm{MT}$ staining were obtained from 10 different, randomly selected microscopic fields per section under a light microscope at a magnification of x200 using a digital camera (Eclipse E200; Nikon Corporation, Tokyo, Japan). The extent of stress-induced inflammatory damage was evaluated by histologic scoring performed by an investigator who was blinded to the group. For statistical analysis, three independent measurements for each specimen were performed. The histologic findings were scored in terms of the epithelial damage, submucosal edema and submucosal inflammatory cells observed (23). The epithelial damage scores were assigned as follows: 0, normal morphology; 1 , mild surface lifting; 2, intraepithelial separation and surface lifting; and 3 , epithelial cell loss to basal cell layer or deeper. Submucosal edema was scored as follows: 0 , normal tissue; 1 , mild focal edema; 2, moderate diffuse edema; and 3, severe edema. Finally, the score for submucosal inflammatory cells was as follows: 0, 0-5 cells/high-power field (HPF); 1, 5-10 cells/HPF; 2, 10-15 cells/HPF; and 3, $\geq 15$ cells/HPF. MT-positive areas, including the mucosal and epithelial layers, were analyzed by Adobe Photoshop (Adobe Inc., Mountain View, CA, USA) and quantified in 10 random fields-of-view per section using NIH ImageJ version 1.62 software (National Institutes of Health, Bethesda, MD, USA).

Immunohistochemical assay. Immunohistochemistry was performed according to the streptavidin-biotin complex method, as described previously $(22,24)$. Briefly, esophageal sections were deparaffinized with xylene and dehydrated with ethanol. All sections were incubated overnight at $4^{\circ} \mathrm{C}$ with primary antibodies, including anti-Nox-4 (1:100; cat. no. ab133303; Abcam, Cambridge, UK), anti-TRPV-1 (1:100; cat. no. NBP1-71774; Novus Biologicals, Ltd., Cambridge, UK); and anti-PAR-2 (1:100; cat. no. ab180953; Abcam). The localization of Nox-4, TRPV-1 and PAR-2 was visualized using 3,3-diaminobenzidine tetrahydrochloride (DAB tablet; Merck KGaA, Darmstadt, Germany) at a concentration of $30 \mathrm{mg} / \mathrm{ml}$ containing $0.03 \% \mathrm{H}_{2} \mathrm{O}_{2}$. Then, sections were counterstained in $2 \%$ methylene green for $12 \mathrm{~min}$ at room 
temperature. Sections were dehydrated in descending ethanol series, washed with xylene for $5 \mathrm{~min}$ at room temperature three times, and mounted in mounting media (Mount-quick; Daido Sangyo Co., Ltd., Kawasaki, Japan). Images of all sections were captured under a light microscope (magnification, x200) with a digital camera (Eclipse E200; Nikon Corporation).

Enzyme linked immunosorbent assays (ELISA). Plasma samples of all mice were obtained and properly processed according to the protocols, as described previously $(21,22)$. Plasma levels of Nox-4, interleukin (IL)-6, IL-8, interferon- $\gamma($ IFN- $\gamma$ ) and tumor necrosis factor- $\alpha$ (TNF- $\alpha$ ) were determined with a competitive ELISA kit (R\&D Systems, Inc., Minneapolis, MN, USA) according to the protocol provided by the manufacturer.

Cell culture. Normal human esophageal epithelial cells (HEECs) were purchased from The American Type Culture Collection (cat. no. ATCC CRL-2629; Manassas, VA, USA), and maintained in keratinocyte serum-free medium, purchased from Gibco (Thermo Fisher Scientific, Inc.), containing 10\% FBS supplemented with $100 \mathrm{U} / \mathrm{ml}$ penicillin and $100 \mathrm{mg} / \mathrm{ml}$ streptomycin under standard cell culture conditions of $37^{\circ} \mathrm{C}$ and a humidified atmosphere with $5 \% \mathrm{CO}_{2}$. The medium was replaced every three days until confluence was reached. Cells between passages 2 to 5 were used in all cell culture experiments.

HEEC treatment, and preparation for Nox-4, PAR-2 and $T R P V-1$ expression determination. HEECs were seeded at a density of $5 \times 10^{3}$ cells/well in 96-well plate in DMEM (Gibco; Thermo Fisher Scientific, Inc.) containing 10\% FBS (Gibco; Thermo Fisher Scientific, Inc.) for 48 h. HEECs were serum-starved for $24 \mathrm{~h}$, and were subsequently were stimulated with trypsin $(0.05$ and $0.1 \mathrm{nM})$, which served as an endogenous PAR-2 agonist, for $0,2,4$ and $8 \mathrm{~h}$. Next, cells were lysed in $200 \mu \mathrm{l}$ cell lysis buffer, and the lysate was harvested using a cell scraper and centrifugation for $15 \mathrm{~min}$ at $12,000 \times \mathrm{g}$ and at $4^{\circ} \mathrm{C}$. Finally, the supernatant was collected, and used to determine the mRNA expression levels of Nox-4, PAR-2 and TRPV-1 by reverse transcription-quantitative polymerase chain reaction (RT-qPCR).

Effect of PAR-2 antibody on Nox-4, TRPV-1, IL-6, IL-8, $I F N-\gamma$ and $T N F-\alpha$ expression levels. The role of PAR-2 on Nox-4, TRPV-1, IL-6, IL-8, IFN- $\gamma$ and TNF- $\alpha$ production by HEECs was investigated using a blocking antibody against the amino-terminal cleavage region of PAR-2 (SAM11; Santa Cruz Biotechnology, Inc., Dallas, TX, USA). Briefly, HEECs were grown to confluence at a density of $5 \times 10^{5}$ cells/well on 96-well culture plate. HEECs were serum-starved for $24 \mathrm{~h}$, and were subsequently treated with or without anti-PAR-2 blocking antibody $(1: 20,000)$ for $2 \mathrm{~h}$, followed by incubation with trypsin $(0.1 \mathrm{nM})$ for $4 \mathrm{~h}$. Subsequently, culture supernatants were centrifuged for $15 \mathrm{~min}$ at $12,000 \mathrm{x} \mathrm{g}$ and at $4^{\circ} \mathrm{C}$. Supernatants were treated with $0.05 \%$ trypsin and maintained at $37^{\circ} \mathrm{C}$ with $5 \% \mathrm{CO}_{2}$ for $5 \mathrm{~min}$. The mRNA expression levels of the genes of interest were measured by RT-qPCR.

Transfection with small interfering RNA (siRNA) targeting $T R P V-1$. siRNA specific to TRPV-1 was purchased from
Santa Cruz Biotechnology, Inc., and Lipofectamine RNA iMAX (Invitrogen; Thermo Fisher Scientific, Inc., Waltham, MA, USA) was used to transfect the siRNA into HEECs according to the manufacturer's protocol. Briefly, cells were seeded at a density of $5 \times 10^{5}$ cells/well on a 6 -well culture plate in keratinocyte serum-free medium containing $10 \%$ FBS, and grown to confluence. HEECs were incubated with control siRNA or TRPV-1 siRNA (20 nmol/l). The siRNAs were purchased from Santa Cruz Biotechnology, Inc. (Dallas, TX, USA). Cells were incubated for $48 \mathrm{~h}$ prior to trypsin treatment $(0.1 \mathrm{nM})$ for $4 \mathrm{~h}$. Subsequently, culture supernatants were harvested, and the mRNA expression levels of the aforementioned proteins were measured by RT-qPCR.

Western blot analysis. HEECs were lysed in lysis buffer [containing $65 \mathrm{mmol} / 1$ Tris- $\mathrm{HCl}(\mathrm{pH} \mathrm{6.8)}, 3.3 \%$ sodium dodecyl sulfate (SDS), $10 \%$ glycerol and $2.2 \%$ bromophenol blue], and the supernatant was collected and stored at $-80^{\circ} \mathrm{C}$. The protein concentration was determined using the bicinchoninic acid protein assay kit. Next, proteins were fractionated by SDS-polyacrylamide gel electrophoresis and then transferred to polyvinylidene difluoride membranes (Immobilon-P; EMD Millipore, Billerica, MA, USA). The membranes were blocked with $5 \%$ bovine serum albumin (BSA) in Tris-buffered saline Tween-20 (TBS-T) at room temperature for $1 \mathrm{~h}$. Subsequent to washing with TBS-T, the membranes were treated with mouse polyclonal anti-TRPV-1 antibody (1:1,000; cat. no. NBP1-71774; Novus Biologicals, Ltd., Cambridge, UK) and $\beta$-actin (1:1,000; cat. no. 3700; Cell Signaling Technology, Inc., Danvers, MA, USA). The membranes were further incubated with HRP-linked secondary antibody (1:10,000; cat. no. 7076; Cell Signaling Technology, Inc.) at room temperature for $1 \mathrm{~h}$. Following washing with TBS-T three times, the protein expression levels were visualized using the Chemi-Lumi One enhanced chemiluminescence system (Nacalai Tesque, Inc., Kyoto, Japan).

$R T$ - $q P C R$. Total RNA was extracted from the esophageal tissues of mice and HEECs using TRIzol reagent (Thermo Fisher Scientific, Inc.) and subjected to FastLane Cell cDNA Kit (Qiagen GmbH, Hilden, Germany). Total RNA (1 $\mu \mathrm{g})$ was reverse transcribed to cDNA with oligo (dT) primers according to the manufacturer's protocol (Qiagen $\mathrm{GmbH}$ ). The obtained cDNA was subjected to qPCR analysis. The thermocycling conditions were as follows: Initial denaturation at $95^{\circ} \mathrm{C}$ for $2 \mathrm{~min}$, followed by 40 cycles of $12 \mathrm{sec}$ at $95^{\circ} \mathrm{C}$ and $60 \mathrm{sec}$ at $60^{\circ} \mathrm{C}$, using the Bio-Rad CFX96 Touch Real-Time PCR detection system (Bio-Rad Laboratories, Inc., Hercules, CA, USA) and Power SYBR Green PCR Master Mix (Applied Biosystems; Thermo Fisher Scientific, Inc.). Serial dilutions of a control sample of cDNA were used as the standard curve for each reaction. All experiments were performed in triplicate. Changes in gene expression were calculated by the $2^{-\Delta \Delta \mathrm{Cq}}$ method (25), and the values were normalized to the levels of $\beta$-actin and GAPDH. The primer sequences used in the present study are listed in Tables I and II. The amount of each mRNA was normalized to $\beta$-actin for the RNA extracted from mice tissues and GAPDH for the RNA extracted from HEECs, respectively. 
Table I. Sequences of mouse primers used in the present study.

\begin{tabular}{|c|c|c|c|}
\hline Gene & Forward $\left(5^{\prime}-3^{\prime}\right)$ & Reverse $\left(5^{\prime}-3^{\prime}\right)$ & Size \\
\hline Nox-4 & TGTTGGGCCTAGGATTGTGTT & AGGGACCTTCTGTGATCCTCG & 125 \\
\hline $\mathrm{Cu} / \mathrm{Zn}-\mathrm{SOD}$ & CAGCATGGGTTCCACGTCCA & CACATTGGCCACACCGTCCT & 168 \\
\hline MnSOD & CACATTAACGCGCAGATCATG & CCAGAGCCTCGTGGTACTTCTC & 100 \\
\hline GPx & GGGCAAGGTGCTGCTCATTG & AGAGCGGGTGAGCCTTCTCA & 269 \\
\hline Catalase & CCAGCGACCAGATGAAGCAG & CCACTCTCTCAGGAATCCGC & 198 \\
\hline TRPV-1 & AGCCATGCTCAATCTGCAC & TGCTGTCTGGCCCTTGTAG & 133 \\
\hline PAR-2 & CAAGGTGCTCATTGGCTTTT & CAGAGGGCGACAAGGTAGAG & 549 \\
\hline IL-6 & CCAGAGATACAAAGAAATGATGG & ACTCCAGAAGACCAGAGGAAAT & 88 \\
\hline IL-8 & CGGCAATGAAGCTTCTGTAT & CCTTGAAACTCTTTGCCTCA & 224 \\
\hline IFN- $\gamma$ & ACACTGCATCTTGGCTTTGC & GCTTTCAATGACTGTGCCGT & 76 \\
\hline TNF- $\alpha$ & AGGCTGCCCCGACTACGT & GACTTTCTCCTGGTATGAGATAGCAA & 70 \\
\hline$\beta$-actin & TATTGGCAACGAGCGGTTC & ATGCCACAGGATTCCATACCC & 75 \\
\hline
\end{tabular}

Nox-4, NADPH oxidase 4; SOD, superoxide dismutase; GPx, glutathione peroxidase; TRPV-1, transient receptor potential vanilloid 1; PAR-2, protease-activated receptor 2 ; IL, interleukin; IFN- $\gamma$, interferon- $\gamma$; TNF- $\alpha$, tumor necrosis factor- $\alpha$.

Table II. Sequences of human primers used in the present study.

\begin{tabular}{lllc}
\hline Gene & \multicolumn{1}{c}{ Forward $\left(5^{\prime}-3^{\prime}\right)$} & \multicolumn{1}{c}{ Reverse $\left(5^{\prime}-3^{\prime}\right)$} & Size \\
Nox-4 & CTCAGCGGAATCAATCAGCTGTG & AGAGGAACACGACAATCAGCCTTAG & 286 \\
PAR-2 & GTTGATGGCACATCCCACGTC & GTACAGGGCATAGACATGGC & 660 \\
TRPV-1 & GGCTGTCTTCATCATCCTGCTGCT & GTTCTTGCTCTCCTGTGCGATCTTGT & 118 \\
IL-6 & GACAGCCACTCACCTCTTCA & CCTCTTTGCTGCTTTCACAC & 120 \\
IL-8 & TCTGCAGCTCTGTGTGAAGGTG & AATTTCTGTGTTGGCGCAGTG & 153 \\
IFN- $\gamma$ & GACCAGAGCATCCAAAAGAGT & ATTGCTTTGCGTTGGACATTC & 143 \\
TNF- $\alpha$ & TTGAGGGTTTGCTACAACATGGG & GCTGCACTTTGGAGTGATCG & 142 \\
GAPDH & TGCACCACCAACTGCTTAGC & GGCATGGACTGTGGTCATGAG & 87
\end{tabular}

Nox-4, NADPH oxidase 4; PAR-2, protease-activated receptor 2; TRPV-1, transient receptor potential vanilloid 1; IL, interleukin; IFN- $\gamma$, interferon- $\gamma$; TNF- $\alpha$, tumor necrosis factor- $\alpha$.

Statistical analysis. All data are expressed in terms of the mean \pm standard deviation. The quantitative analysis of histological damage score, MT staining and body weight gain was conducted by Student's t-test. The mRNA and plasma levels of Nox-4, antioxidant enzymes, inflammatory cytokines, as well as TRPV-1 and PAR-2, were also analyzed by Student's t-test. The mRNA levels of Nox-4, PAR-2 and TRPV-1 in cell culture experiments were analyzed by one-way analysis of variance with Fisher's protected least significant difference test. Differences between groups were considered as statistically significant at $\mathrm{P}<0.05$.

\section{Results}

Stress-induced esophageal inflammation in mice. In the current study, 8-week-old male C57BL/6J mice were subjected to restraint stress for 2 weeks to observe the stress-induced inflammatory response in the esophagus. The histopathological analysis by $H \& E$ staining revealed that pathological changes in the esophagus were not observed in the control group. In the esophagus of the CRS group, however, mild infiltration of inflammatory cells in the submucosa, basal cell hyperproliferation, papillary hypertrophy, epithelial hyperkeratinization, squamous cell expansion and an increase in the number of fibrin cells were observed (Fig. 1A). The mucosal damage scores in the esophageal tissue of mice are displayed in Fig. 1B. Compared with the control group, the histological damage score in the CRS group was markedly increased $(0.38 \pm 0.09$ in the control vs. $1.23 \pm 0.05$ in the CRS group; $\mathrm{P}<0.01)$. These results were consistent with the typical histological findings associated with low-grade reflux esophagitis (26). In addition, the MT staining results revealed that stress increased esophageal interstitial fibrosis as compared with the control mice (Fig. 1C and D).

Stress-induced body weight loss in mice. The body weight of mice was monitored and measured during the 2-week stress period. Body weight gain was significantly reduced in CRS 
Table III. Stress-induced weight loss in mice.

\begin{tabular}{lrrr}
\hline Parameter & \multicolumn{1}{c}{ Control } & CRS & P-value \\
\hline Body weight gain (g) & $1.37 \pm 0.02$ & $1.04 \pm 0.04$ & $<0.001$ \\
Food intake (mg) & $133.5 \pm 2.46$ & $130.7 \pm 2.46$ & 0.441 \\
\hline
\end{tabular}

Body weight gain and food intake were monitored every 2 days during the stress period. Values are expressed relative to the control mice. Data are expressed as the mean \pm standard deviation $(n=10)$. Differences between groups were analyzed by the Student's t-test. CRS, chronic restraint stress.

A

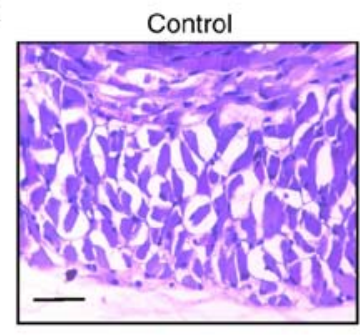

C

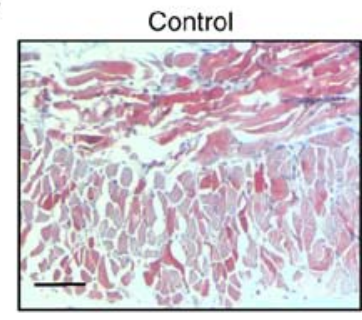

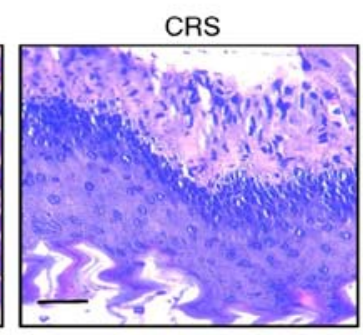

CRS

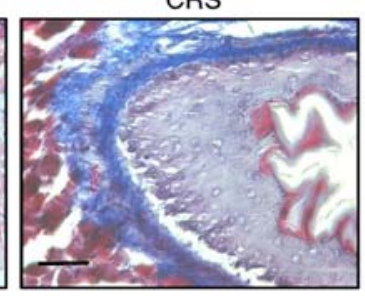

B

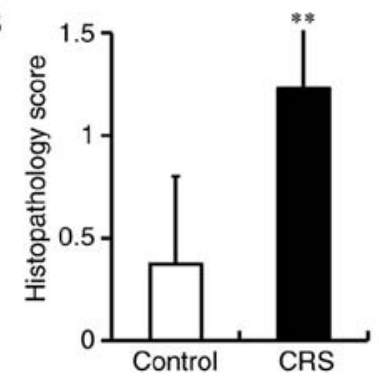

D

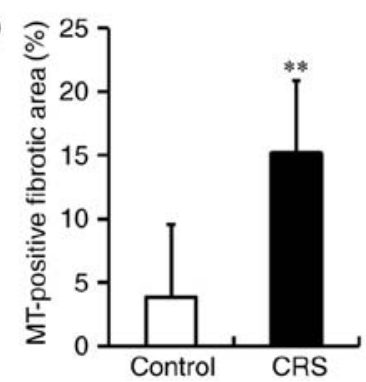

Figure 1. Stress-induced esophageal inflammation in mice. Mice were subjected to restraint stress by immobilization for 2 h/day for 2 weeks. Subsequently, esophageal tissues were collected from CRS and control (non-stressed) mice. (A) Hematoxylin and eosin staining, showing the accumulation of mononuclear cells in esophageal tissue from CRS mice (magnification, x200; scale bar, $50 \mu \mathrm{m}$ ); (B) Histopathological damage scores; (C) MT staining (magnification, x200; scale bar, $50 \mu \mathrm{m}$ ) and (D) MT-positive fibrotic area in esophageal tissue, indicating interstitial fibrosis (mucosal and epithelial layer) in CRS mice. Differences between groups were analyzed by the Student's t-test, and data are expressed as the mean \pm standard deviation ( $\mathrm{n}=10)$. ${ }^{* *} \mathrm{P}<0.01 \mathrm{vs}$. control mice. MT, Masson's trichrome; CRS, chronic restraint stress.

mice as compared with that in the non-stressed control mice (Table III). Each group of mice consumed similar amounts of food ( 130 mg/g/day; P>0.05).

Stress-induced ROS generation in the esophagi of mice. It has previously been reported that chronic stress evokes ROS production in adipose tissue and the colon $(22,24)$. To determine whether stress induces ROS generation in the esophagus, the current study analyzed the expression of Nox-4 in mice by immunohistochemical analysis, RT-qPCR and ELISA. The data revealed that 2 weeks of restraint stress resulted in an increase in Nox-4 expression in the mucosal and epithelial layers of the esophagus (Fig. 2A), significantly elevated plasma levels of Nox-4 (Fig. 2B) and marked upregulation of Nox-4 mRNA expression (Fig. 2C), when compared with the levels in control mice.

Stress reduces the antioxidant enzymes in the esophagi of mice. Antioxidant enzymes serve an important role against oxidative stress in various types of cells and tissues $(22,24)$. Herein, the expression levels of antioxidant enzymes were examined using RT-qPCR. After a 2-week period of stress, the mRNA expression levels of antioxidant enzymes, including Mn-superoxide dismutase (MnSOD), Cu/Zn-SOD, glutathione peroxidase $(\mathrm{GPx})$ and catalase, were significantly reduced in stressed mice compared with those in non-stressed control mice (Fig. 2D-G).

Stress increases the esophageal expression of TRPV-1 and $P A R-2$. Earlier studies have demonstrated that TRPV-1 and PAR-2 receptors regulate VH (12). In the present study, the esophageal expression levels of TRPV-1 and PAR-2 were determined by immunohistochemistry and RT-qPCR. The results revealed that TRPV-1 and PAR-2 were localized in the luminal layers of the esophageal squamous epithelia of stressed mice (Fig. 3A and B). Furthermore, stress significantly increased the esophageal mRNA expression levels of TRPV-1 and PAR-2 as compared with those in non-stressed control mice (Fig. 3C and D).

Stress augments the expression of inflammatory cytokines in mice. After 2 weeks of restraint stress, significant increases 
A

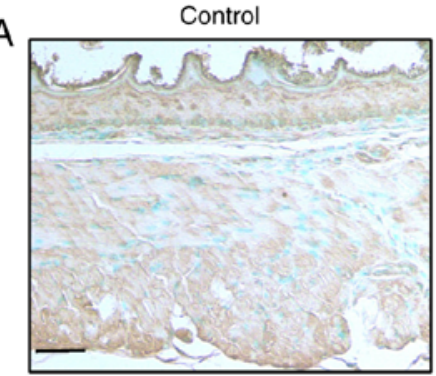

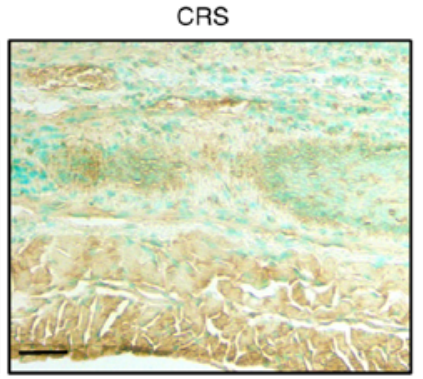
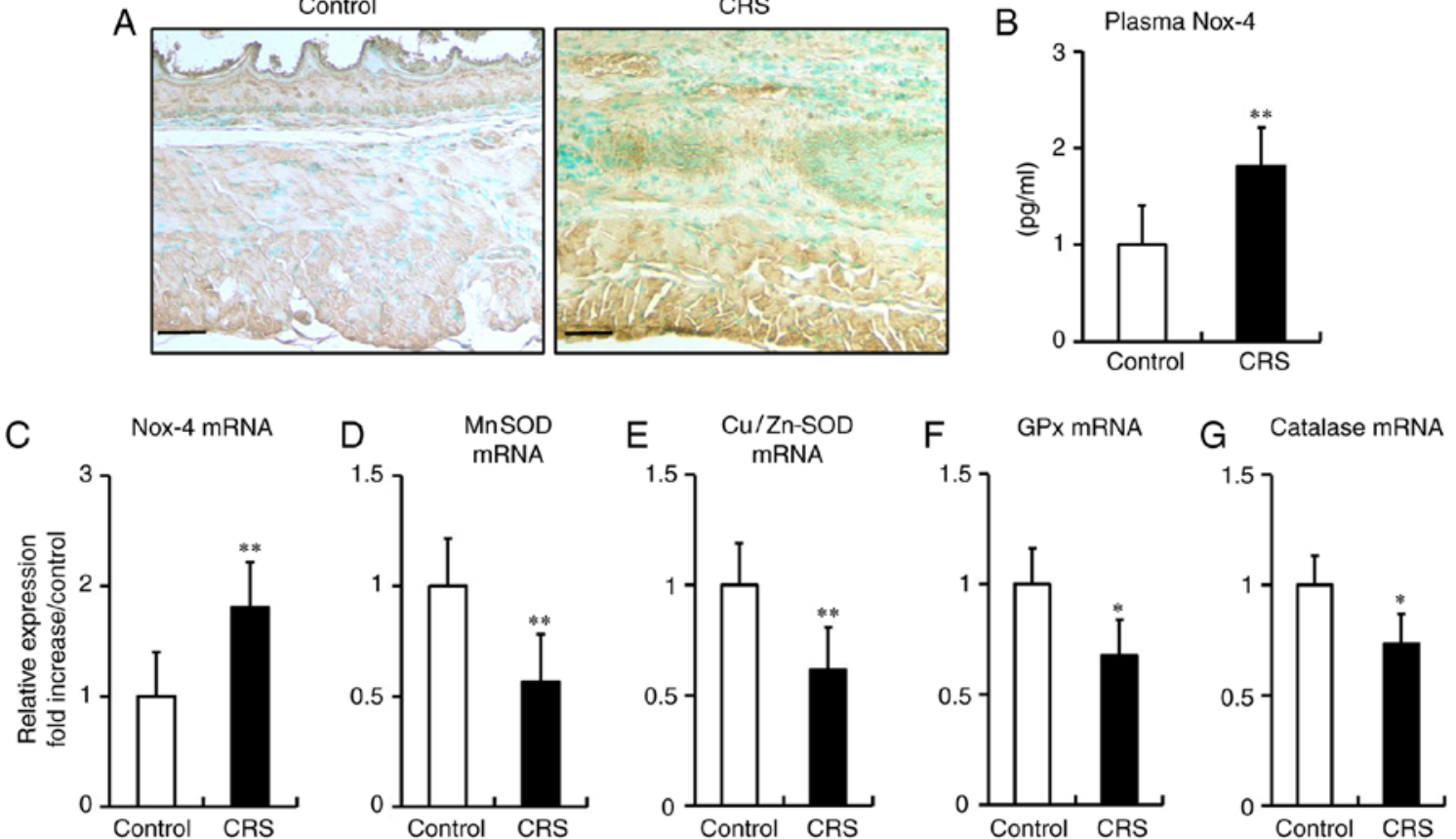

Figure 2. Stress-induced reactive oxygen species generation and reduction of antioxidant enzyme levels in the esophagi of mice. (A) Immunohistochemical staining for Nox-4 in esophageal tissue (magnification, x200; scale bar, $50 \mu \mathrm{m}$ ). (B) Plasma Nox-4 expression examined by ELISA (control, 0.98 \pm 0.14 ; CRS 1.78 \pm 0.18 ). (C) Nox-4 mRNA, (D) MnSOD, (E) Cu/Zn-SOD, (F) GPx and (G) catalase mRNA expression levels, assessed by reverse transcription-quantitative polymerase chain reaction. Differences between groups were analyzed by the Student's t-test, and data are expressed as the mean \pm standard deviation $(\mathrm{n}=10)$. ${ }^{*} \mathrm{P}<0.05,{ }^{* *} \mathrm{P}<0.01$ vs. control mice. CRS, chronic restraint stress; Nox-4, NADPH oxidase 4; SOD, superoxide dismutase; GPx, glutathione peroxidase.
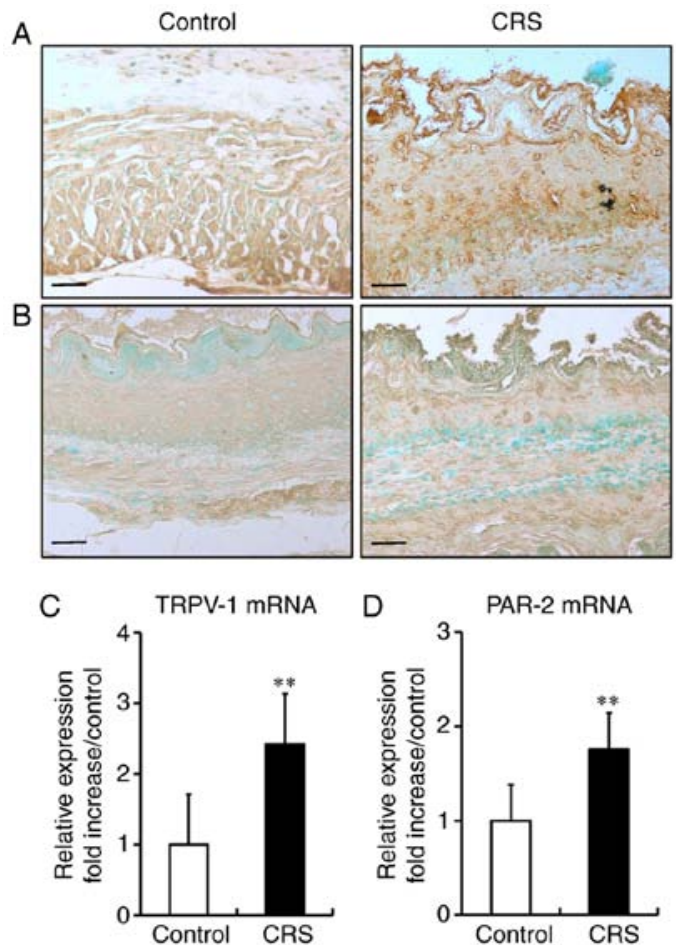

$\mathrm{D}$

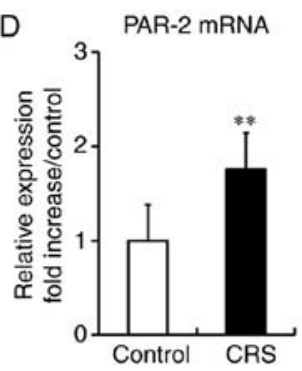

Figure 3. Stress increased the esophageal expression levels of TRPV-1 and PAR-2. Mice were individually subjected to $2 \mathrm{~h}$ /day of restraint stress for 2 weeks, and then esophageal tissues were examined. (A) TRPV-1 and (B) PAR-2 expression in the esophageal mucosa was analyzed by immunohistochemistry (magnification, x200; scale bar, $50 \mu \mathrm{m}$ ). (C) TRPV-1 and (D) PAR-2 mRNA expression levels were examined by reverse transcription-quantitative polymerase chain reaction. Differences between groups were analyzed by the Student's t-test, and data are expressed as the mean \pm standard deviation $(n=10)$. ${ }^{* *} \mathrm{P}<0.01$ vs. control mice. CRS, chronic restraint stress; TRPV-1, transient receptor potential vanilloid 1; PAR-2, protease-activated receptor 2. were observed in the mRNA expression levels of IL-6, IL-8, IFN- $\gamma$ and TNF- $\alpha$ in the esophageal tissues of the CRS group, as compared with those in the non-stressed control group (Fig. 4A, B, C and D). Furthermore, the plasma concentration levels of IL-6, IL-8, IFN- $\gamma$ and TNF- $\alpha$ were significantly elevated in stressed mice, in parallel with the changes in mRNA expression in the esophagus (Fig. 4E, F, G and H).

Expression levels of Nox-4, PAR-2 and TRPV-1 in cultured $H E E C s$. Reflux of proteases, including trypsin, has been previously reported to cause damage to the esophageal mucosa $(16,18)$; however, the mechanism underlying this effect remains unclear. In the present study, the effect of trypsin on the expression levels of Nox-4, PAR-2 and TRPV-1 were investigated. HEECs were incubated with trypsin at the indicated concentrations and time periods. Nox-4, PAR-2 and TRPV-1 expression levels were examined at $4 \mathrm{~h}$ after incubating with different concentrations of trypsin $(0,0.05$ and $0.1 \mathrm{nM})$, or at the different time points $(0,2,4$ and 8$)$ following incubation with trypsin $(0.1 \mathrm{nM})$. It was observed that trypsin increased the mRNA expression levels of Nox-4, PAR-2 and TRPV-1 in HEECs in a time- and dose-dependent manner (Fig. 5A-F). Trypsin at a concentration of $0.1 \mathrm{nM}$ was used in subsequent in vitro experiments.

Effects of PAR-2 blocking antibody on Nox-4, TRPV-1, IL-6, $I L-8, I F N-\gamma$ and TNF- $\alpha$ expression levels. As shown in Fig. 6A-F, the mRNA expression levels of Nox-4, TRPV-1, IL-6, IL-8, IFN- $\gamma$ and TNF- $\alpha$ were significantly increased when the cells were stimulated with trypsin, serving as a natural PAR-2 agonist, for $4 \mathrm{~h}$. Notably, pretreatment with a blocking antibody against PAR-2 resulted in significant 

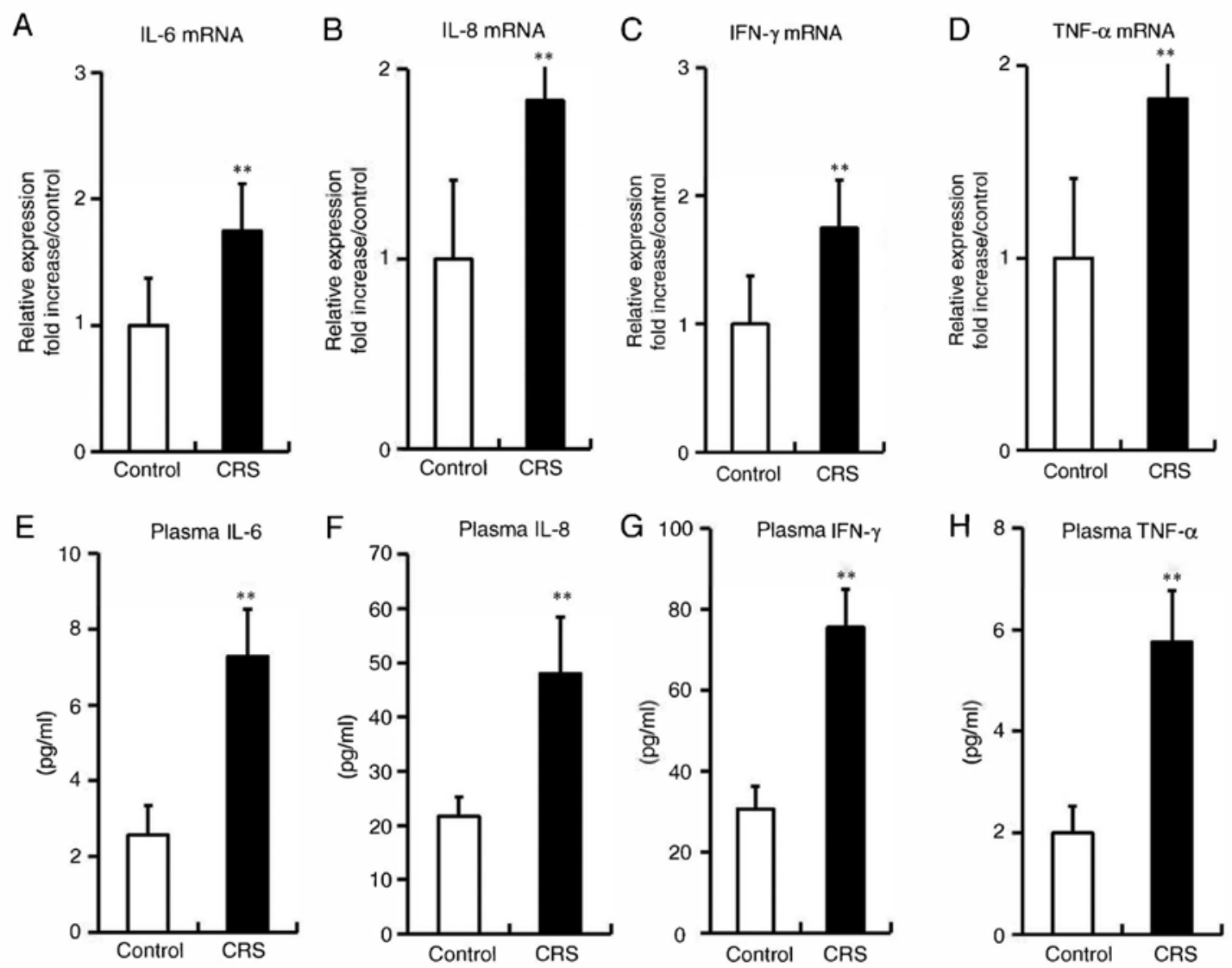

Figure 4. Stress augmented the expression levels of inflammatory cytokines in mice. (A) IL-6, (B) IL-8, (C) IFN- $\gamma$ and (D) TNF- $\alpha$ mRNA expression levels

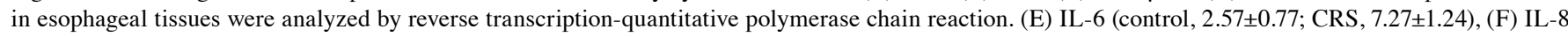
(control, 21.68 \pm 3.59 ; CRS, 47.96 \pm 10.38 ), (G) IFN- $\gamma$ (control, 30.65 \pm 5.67 ; CRS, 75.55 \pm 9.39 ) and (H) TNF- $\alpha$ (control, 2.01 \pm 0.53 ; CRS, 5.75 \pm 1.02 ) plasma levels were analyzed by ELISA. Differences between groups were analyzed by the Student's t-test, and data are expressed as the mean \pm standard deviation $(\mathrm{n}=10)$. ${ }^{* *} \mathrm{P}<0.01$ vs. control mice. CRS, chronic restraint stress; IL, interleukin; IFN- $\gamma$, interferon- $\gamma$; TNF- $\alpha$, tumor necrosis factor- $\alpha$.

inhibition of the mRNA expression of these inflammatory cytokines in HEECs stimulated with trypsin.

Effects of TRPV-1 knockdown on PAR-2, Nox-4, IL-6,IL-8, $I F N-\gamma$ and TNF- $\alpha$ expression levels. The effects of TRPV-1 knockdown on the mRNA levels of PAR-2, Nox-4 and inflammatory cytokines were examined in cultured HEECs. HEECs were incubated with or without TRPV-1 siRNA ( $20 \mathrm{nmol} / \mathrm{l})$ for $48 \mathrm{~h}$, followed by the stimulation with trypsin $(0.1 \mathrm{nM})$ for $4 \mathrm{~h}$. In cells without trypsin treatment, transfection with siRNA specific to TRPV-1 suppressed the gene and protein expression levels of TRPV-1 as compared with that of control-transfected HEECs (Fig. 7A). The trypsin-treated cells exhibited significantly increased mRNA expression levels of Nox-4, PAR-2 and inflammatory cytokines, including IL-6, IL- 8 , IFN- $\gamma$, and TNF- $\alpha$, compared with the control group. Importantly, knockdown of TRPV-1 significantly suppressed the mRNA expression levels of Nox-4, PAR-2 and inflammatory cytokines (IL-6, IL-8, IFN- $\gamma$, and TNF- $\alpha$ ) compared with the trypsin-treated cells. (Fig. 7B-G).

Collectively, the present findings suggested that 2-week stressed mice showed esophageal inflammation and fibrosis via ROS accumulation and antioxidants suppression. Furthermore, stress-activated PAR-2 and TRPV-1 were involved in ROS production and inflammatory cytokine expression.

\section{Discussion}

The present study revealed that chronic restraint stress conducted in mice over a 2 -week period resulted in reduced body weight gain, and increased esophageal inflammation and ROS production. Chronic stress also suppressed the expression of genes regulating the antioxidant system, such as SOD, catalase and GPx. Furthermore, 2 weeks of stress elevated the levels of TRPV-1 and PAR-2 receptor in the esophagi of mice, and significantly increased the inflammatory cytokines in the blood circulation and esophageal tissue.

Our previous study reported that 2 weeks of restraint stress induced the shrinkage of inguinal fat pad, and significant increase in lipolysis and free fatty acid (FFA) concentration (21). In addition, our previous results indicated that restraint stress increased FFAs followed by lipolysis and evoked an inflammatory response in adipose tissue of non-obese subjects without alterations in diet. Similar findings were reported in the present study, which demonstrated that stress reduced the body weight gain by lipolysis and FFA release in mice, without changes observed in the food intake.

In a rodent chronic stress model, Nox was reported to be a key factor in stress-induced oxidative stress, and repeated restraint stress promoted depression-like behavior through the upregulation of Nox (27). The membrane-bound multimeric Nox complex is an enzyme known to generate ROS. The 
A

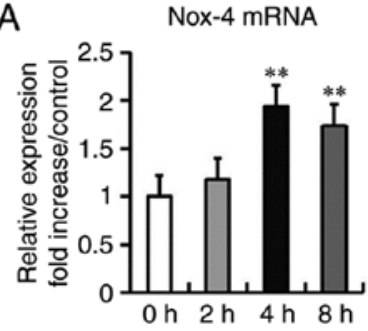

C

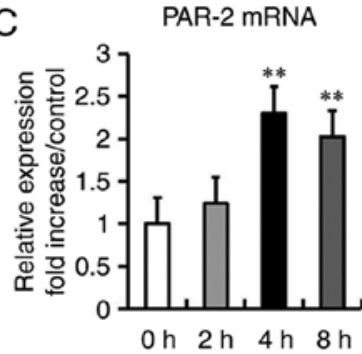

$\mathrm{E}$

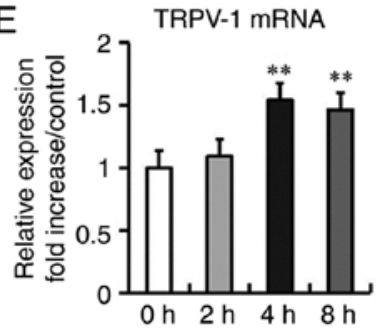

B

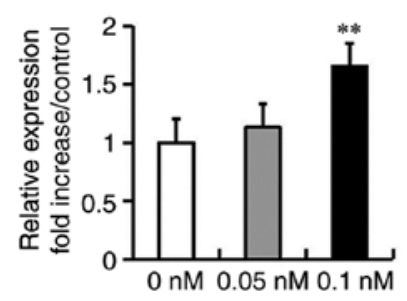

D

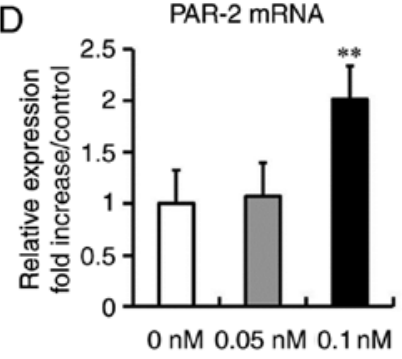

$\mathrm{F}$

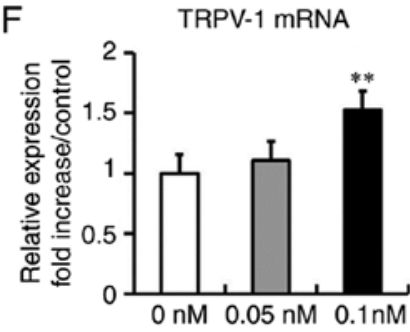

Figure 5. Nox-4, PAR-2 and TRPV-1 expression in HEECs. Serum-starved HEECs were treated with trypsin, which increased Nox-4, PAR-2 and TRPV-1 mRNA expression levels in a time- and dose-dependent manner. Effect of different (A) incubation times and (B) trypsin concentrations on Nox-4 expression. Effect of different (C) incubation times and (D) trypsin concentrations on PAR-2 expression. Effect of different (E) incubation times and (F) trypsin concentrations on TRPV-1 expression. Data are expressed as the mean \pm standard deviation $(n=5)$. Differences between groups were analyzed with one-way analysis of variance, followed by Fisher's protected least significant difference test. ${ }^{* *} \mathrm{P}<0.01$ vs. untreated group. Nox-4, NADPH oxidase 4; HEECs, human esophageal epithelial cells; TRPV-1, transient receptor potential vanilloid 1; PAR-2, protease-activated receptor 2 .

oxidase family is composed of five Nox members, including Nox1-5, among which Nox-4 is present in the epithelium. In the gastrointestinal tract, one of the main sources of ROS is the Nox enzyme (28). The present study indicated that the mRNA expression and plasma concentration of Nox-4 were significantly increased in stressed mice (Fig. 2A-C), while the mRNA expression of antioxidants, such as MnSOD, $\mathrm{Cu} / \mathrm{Zn}$-SOD, GPx and catalase, were markedly reduced in stressed mice (Fig. 2D-G). Although stress-induced expression of Nox enzymes (particularly Nox-4) in the esophagus has rarely been studied, the results of the current study suggested that Nox-4 may serve an important role in stress-related ROS accumulation.

Pro- and anti-inflammatory mechanisms clearly depend on the type and intensity of stressors. Thus far, it is been reported that acute stressors enhance immune function, whereas chronic stressors are suppressive (2). Peng et al (29) established a chronic stress model, and reported that inflammatory cytokines, including TNF- $\alpha$, IL-18 and IL-1 $\beta$, were significantly increased in the experimental group after a 4-week period of stress. Similarly, the current study also demonstrated that the

levels of mRNA expression and circulatory concentrations of inflammatory cytokines (IL-6, IL-8, IFN- $\gamma$ and TNF- $\alpha$ ) in the esophageal tissues and plasma of stressed mice were significantly increased compared to non-stressed control mice (Fig. 4A-H).

The current study also examined the gene expression and epithelial localization of TRPV-1 and PAR-2 within the esophageal mucosa of stressed mice. Compared with the control group, stressed mice exhibited significantly increased expression levels of TRPV-1 and PAR-2 (Fig. 3A-D). Subsequent in vitro experiments investigated the role of PAR-2 activation by trypsin, a PAR-2 agonist. It was observed that trypsin induced upregulation of Nox-4, PAR-2 and TRPV-1 in HEECs in a time- and dose-dependent manner (Fig. 5A-F). In addition, the trypsin-mediated production of inflammatory cytokines in HEECs was significantly suppressed by pretreatment with a PAR-2 blocking antibody. These results suggested that reflux of duodenal fluid containing trypsin, whose release is induced by stress, can increase ROS-dependent PAR-2, TRPV-1 and cytokine production in esophageal epithelial cells, consequently leading to esophageal inflammation (Fig. 6A-F).

To further investigate the role of TRPV-1 in esophageal inflammation, the present study also measured the mRNA levels of PAR-2, Nox-4 and inflammatory cytokines (IL-6, IL-8, IFN- $\gamma$ and TNF- $\alpha$ ) in HEECs using TRPV-1 knockdown by siRNA. It was observed that siRNA specific to TRPV-1 suppressed the mRNA and protein expression of TRPV-1 in HEECs without trypsin stimulation (Fig. 7A). It is known that TRPV-1 is activated by a number of agonists and endogenous chemical mediators, such as anandamide or leukotrienes. Increased temperature was a well-established pathological activator of TRPV-1 under certain conditions. In addition, local acidification $(\mathrm{pH}<6.0)$ is also able to activate TRPV-1, and cause pain and inflammation (18). The role of TRPV-1 in pain sensation has been clearly demonstrated by the advent of TRPV-1 knockout mice (30). TRPV-1/- mice exhibited impaired thermal sensitivity to pain when triggered by heat or capsaicin. In addition, TRPV $-1^{-/}$mice exhibited ameliorated edema, vasodilatation and inflammatory cell infiltration caused by nociceptor overstimulation at the site of neurogenic injury. In the present study, it was observed that knockdown of TRPV-1 in cultured HEECs significantly suppressed the mRNA expression levels of Nox-4, PAR- 2 and inflammatory cytokines (IL-6, IL-8, IFN- $\gamma$ and TNF- $\alpha$ ) (Fig. 7B-G). Taken together, these results indicated that trypsin, whose release is induced by stress, markedly increased ROS accumulation and the expression of inflammatory cytokines in HEECs through a PAR-2-dependent and TRPV-1-dependent manner.

Previous studies have demonstrated that PAR-2 is expressed in various types of cells and tissues, including the esophagus $(26,31)$, and is activated by trypsin and mast cell tryptase, which serve an important role in the pathogenesis of GERD (31), as well as esophageal VH (32). Early studies reported that activation of PAR-2 excites nociceptive neurons and induces visceral hyperalgesia $(33,34)$. Amadesi et al (20) investigated TRPV-1, a cation channel activated by capsaicin, protons and noxious heat, which contributes to PAR-2-induced hyperalgesia, and observed that PAR-2 sensitized TRPV-1 through a PKC-dependent 
A

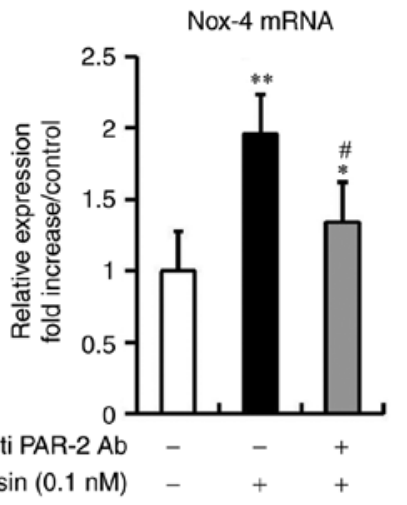

D

IL-8 mRNA

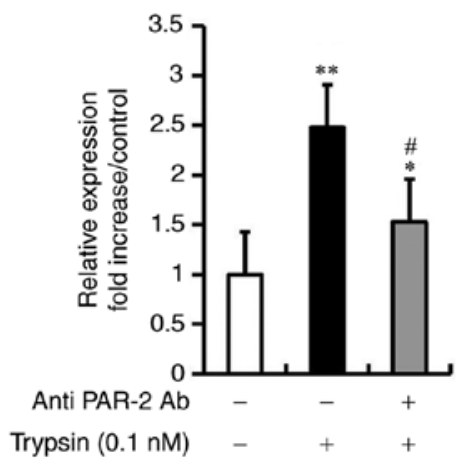

B

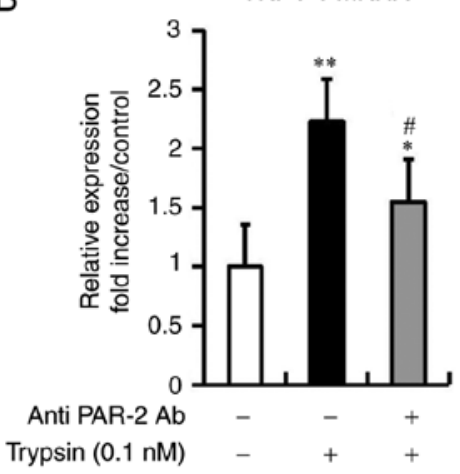

E

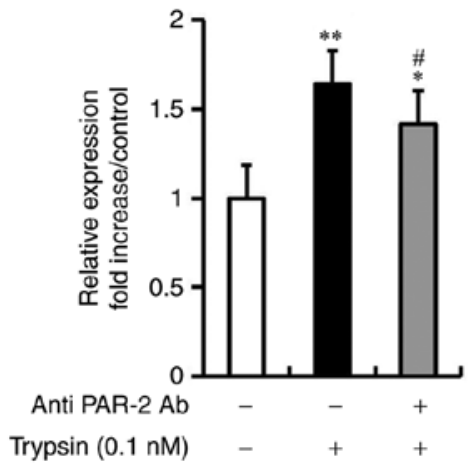

C

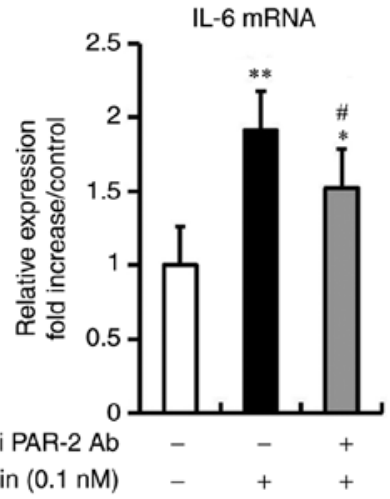

$\mathrm{F}$

TNF- $\alpha$ mRNA

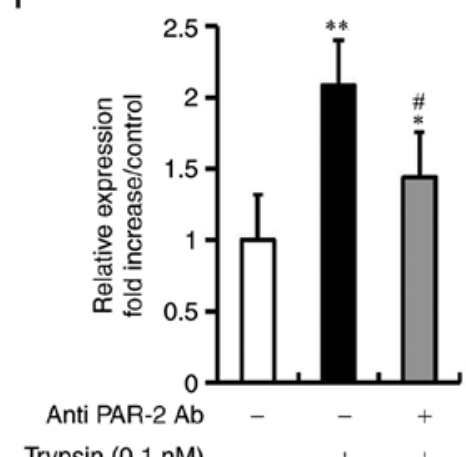

Figure 6. Effects of PAR-2 blocking antibody on Nox-4, TRPV-1, IL-6, IL-8, IFN- $\gamma$ and TNF- $\alpha$ expression levels in human esophageal epithelial cells. Serum-starved cells were preincubated with PAR-2 blocking antibody $(20 \mu \mathrm{g} / \mathrm{ml})$ for $2 \mathrm{~h}$, and then stimulated by trypsin ( $0.1 \mathrm{nM})$ for $4 \mathrm{~h}$. (A) Nox-4, (B) TRPV-1, (C) IL-6, (D) IL-8, (E) IFN- $\gamma$ and (F) TNF- $\alpha$ mRNA expression levels were determined using reverse transcription-quantitative polymerase chain reaction. Data are expressed as the mean \pm standard deviation $(n=5)$. Differences between groups were analyzed with one-way analysis of variance, followed by Fisher's protected least significant difference test. ${ }^{*} \mathrm{P}<0.5,{ }^{* *} \mathrm{P}<0.01$ vs. control group; ${ }^{*} \mathrm{P}<0.05$ vs. trypsin-treated group. PAR-2, protease-activated receptor 2; Nox-4, NADPH oxidase 4; TRPV-1, transient receptor potential vanilloid 1 ; IL, interleukin; IFN- $\gamma$, interferon- $\gamma$; TNF- $\alpha$, tumor necrosis factor- $\alpha$.
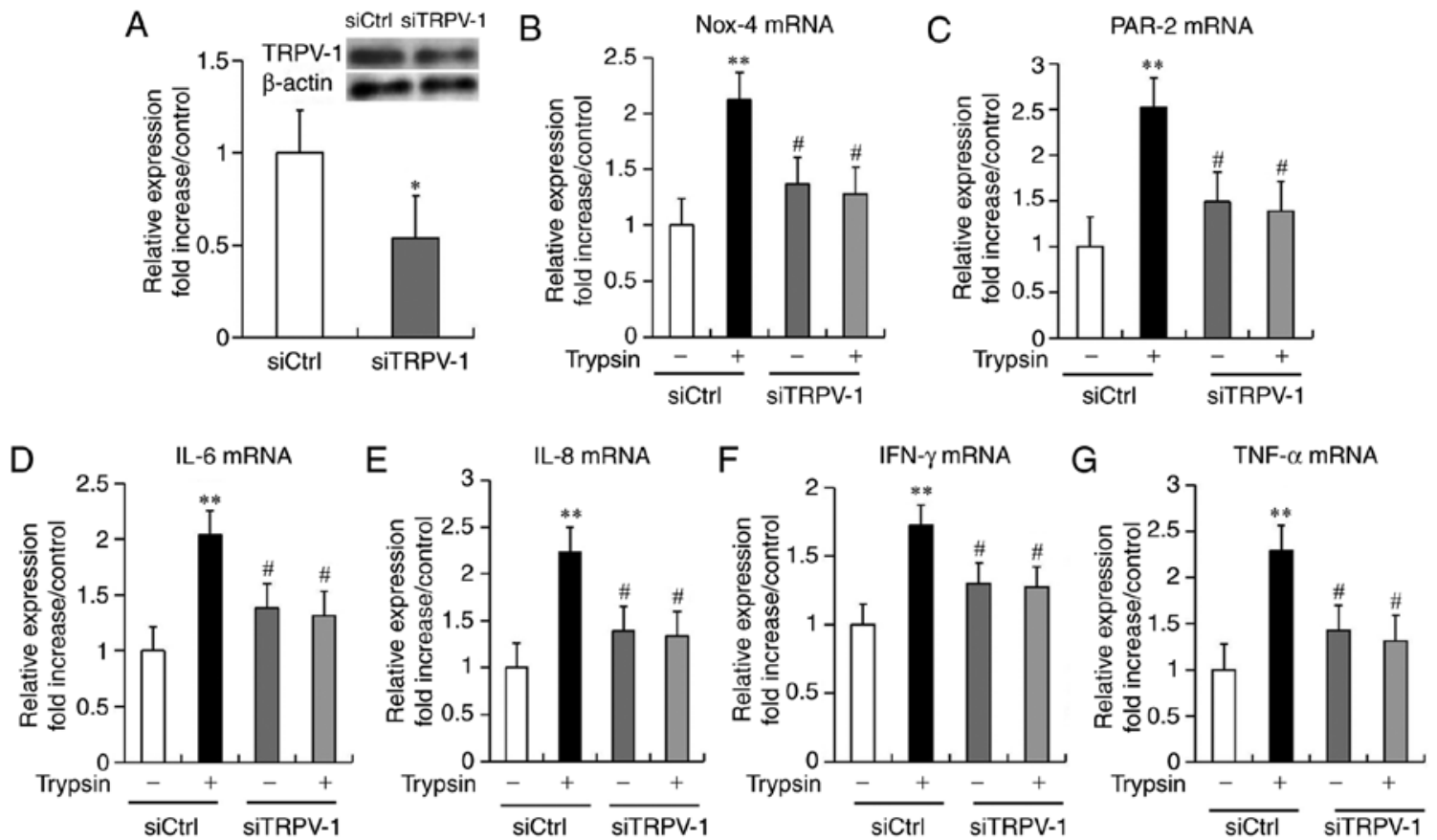

Figure 7. Effects of siTRPV-1 on Nox-4, PAR-2, IL-6, IL-8, IFN- $\gamma$ and TNF- $\alpha$ expression in human esophageal epithelial cells. Serum-starved cells were preincubated with or without siTRPV-1 (20 nmol/l) for $48 \mathrm{~h}$ before stimulation with trypsin $(0.1 \mathrm{nM})$ for $4 \mathrm{~h}$. (A) TRPV-1 expression levels in transfected cells. (B) Nox-4, (C) PAR-2, (D) IL-6, (E) IL-8, (F) IFN- $\gamma$ and (G) TNF- $\alpha$ mRNA expression levels were determined using reverse transcription-quantitative polymerase chain reaction. Data are expressed as the mean \pm standard deviation $(n=5)$. Differences between groups were analyzed with one-way analysis of variance, followed by Fisher's protected least significant difference test. ${ }^{*} \mathrm{P}<0.05 ;{ }^{* *} \mathrm{P}<0.01$ vs. siCtrl untreated group; ${ }^{*} \mathrm{P}<0.05$ vs. siCtrl treated group. TRPV-1, transient receptor potential vanilloid 1; siTRPV-1, TRPV-1 siRNA; siCtrl, control siRNA; Nox-4, NADPH oxidase 4; PAR-2, protease-activated receptor 2; IL, interleukin; IFN- $\gamma$, interferon- $\gamma$; TNF- $\alpha$, tumor necrosis factor- $\alpha$. 
mechanism to cause sustained thermal hyperalgesia. Similarly, the present study indicated that chronic stress may result in esophageal hypersensitivity through the activation of TRPV-1 and PAR-2, which are two essential receptors in the pathogenesis of $\mathrm{VH}$.

There is a possible mechanism associated with PAR-induced dilated intercellular spaces (DIS), which are involved in stress-induced VH. It has been demonstrated that increased PAR-2 expression was observed in all layers of the esophageal mucosa of GERD patients, and served a potential role in increased epithelial permeability and DIS, which in result induced PAR-2 expression in superficial and deep layers of the esophageal squamous epithelium (26). Consistent with these findings, activation of PAR-2 has been reported to induce epithelial barrier dysfunction and disruption of epithelial tight junctions, leading to dilation of tight junctions and increased trans-epithelial permeability $(35,36)$. It has also been suggested that TRPV-1 can be activated by weak gastric acid (37). Therefore, in the present study, it was hypothesized that increased epithelial permeability and DIS induced by PAR-2 further caused activation of TRPV-1 due to physiologic and/or pathologic gastroesophageal reflux in mice.

In conclusion, although it is known that stress induces overproduction of ROS and suppresses the expression of antioxidants, studies involving the role of Nox-4 in stress-induced ROS accumulation are limited. Therefore, the present study further confirmed the notion of stress-induced disruption of oxidant/antioxidant balance, and investigated the role of Nox-4 in that process. Furthermore, recent studies have reported that stress can affect esophageal hypersensitivity; however, the underlying mechanisms remain unknown. In the present study, the possible mechanism of stress-activated PAR-2 and TRPV-1 was investigated, which may provide new insights on understanding the pathogenesis of VH. However, a corollary study should be conducted in the future to clearly elucidate the mechanisms underlying stress-induced esophageal inflammation and $\mathrm{VH}$.

\section{Acknowledgements}

The authors would like to thank Professor Zhonggao Wang and Professor Jiande Chen for the careful reading and editing of this manuscript.

\section{Funding}

Work in the group led by MY and KA was supported by The Xinjiang Uygur Autonomous Region Natural Science Foundation Program (grant no. 2018D01C134).

\section{Availability of data and materials}

All data generated or analyzed during this study are included in this published article.

\section{Authors' contributions}

WW, MY, AiA, KT, AzA and KA contributed to the conception and experimental design of the study, and interpretation of the results. WW, MY, AiA, AlA, YL, YJ, MA and ZL conducted the experiments and/or helped with data analysis. WW and MY wrote the manuscript. WW, MY, AiA, KT, AzA and KA are responsible for the integrity of the work as a whole. All authors revised the article and approved the final version to be published.

\section{Ethics approval and consent to participate}

The study protocol was approved by the Animal Care and Use Committee of the People's Hospital of Xinjiang Uygur Autonomous Region (protocol no. KY201803703; Urumqi, China). The study was completed based on the Guidelines for the Care and Use of Laboratory Animals published by the National Institutes of Health.

\section{Patient consent for publication}

Not applicable.

\section{Competing interests}

The authors declare that they have no competing interests.

\section{References}

1. Landsbergis PA: The changing organization of work and the safety and health of working people: A commentary. J Occup Environ Med 45: 61-72, 2003.

2. Liu YZ, Wang YX and Jiang CL: Inflammation: The common pathway of stress-related diseases. Front Hum Neurosci 11: 316, 2017.

3. Zafir A and Banu N: Modulation of in vivo oxidative status by exogenous corticosterone and restraint stress in rats. Stress 12: 167-177, 2009.

4. Halliwell B: Oxidative stress and neurodegeneration: Where are we now? J Neurochem 97: 1634-1658, 2006.

5. Linares V, Sánchez DJ, Bellés M, Albina L, Gómez M and Domingo JL: Pro-oxidant effects in the brain of rats concurrently exposed to uranium and stress. Toxicology 236: 82-91, 2007.

6. Bedard K and Krause KH: The NOX family of ROS-generating NADPH oxidases: Physiology and pathophysiology. Physiol Rev 87: 245-313, 2007.

7. Lee KW, Kim JB, Seo JS, Kim TK, Im JY, Baek IS, Kim KS, Lee JK and Han PL: Behavioral stress accelerates plaque pathogenesis in the brain of $\mathrm{Tg} 2576$ mice via generation of metabolic oxidative stress. J Neurochem 108: 165-175, 2009.

8. Kondo $\mathrm{T}$ and Miwa $\mathrm{H}$ : The role of esophageal hypersensitivity in functional heartburn. J Clin Gastroenterol 51: 571-578, 2017.

9. Fass R, Naliboff BD, Fass SS, Peleg N, Wendel C, Malagon IB and Mayer EA: The effect of auditory stress on perception of intraesophageal acid in patients with gastroesophageal reflux disease. Gastroenterology 134: 696-705, 2008.

10. Schey R, Dickman R, Parthasarathy S, Quan SF, Wendel C, Merchant J, Powers J, Han B, van Handel D and Fass R: Sleep deprivation is hyperalgesic in patients with gastroesophageal reflux disease. Gastroenterology 133: 1787-1795, 2007.

11. Bradley LA, Richter JE, Pulliam TJ, Haile JM, Scarinci IC, Schan CA, Dalton CB and Salley AN: The relationship between stress and symptoms of gastroesophageal reflux: The influence of psychological factors. Am J Gastroenterol 88: 11-19, 1993.

12. Altomare A, Luca Guarino Sara Emerenziani MP, Cicala M, Drewes AM, Krarup AL, Brock C, Lottrup C, Frøkjaer JB, Souza RF, Nardone G and Compare D: Gastrointestinal sensitivity and gastroesophageal reflux disease. Ann N Y Acad Sci 1300: 80-95, 2013

13. Souza RF: Bringing GERD management up to PAR-2. Am J Gastroenterol 105: 1944-1946, 2010.

14. Kandulski A, Wex T, Mönkemüller K, Kuester D, Fry LC, Roessner A and Malfertheiner P: Proteinase-activated receptor-2 in the pathogenesis of gastroesophageal reflux disease. Am J Gastroenterol 105: 1934-1943, 2010. 
15. O'Brien PJ, Molino M, Kahn M and Brass LF: Protease activated receptors: Theme and variations. Oncogene 20: 1570-1581, 2001.

16. Yoshida N, Katada K, Handa O, Takagi T, Kokura S, Naito Y, Mukaida N, Soma T, Shimada Y, Yoshikawa T and Okanoue T: Interleukin-8 production via protease-activated receptor 2 in human esophageal epithelial cells. Int J Mol Med 19: 335-340, 2007.

17. Vergnolle N, Bunnett NW, Sharkey KA, Brussee V, Compton SJ, Grady EF, Cirino G, Gerard N, Basbaum AI, Andrade-Gordon P, et al: Proteinase-activated receptor-2 and hyperalgesia: A novel pain pathway. Nat Med 7: 821-826, 2001.

18. Bielefeldt K and Davis BM: Differential effects of ASIC3 and TRPV1 deletion on gastroesophageal sensation in mice. Am J Physiol Gastrointest Liver Physiol 294: G130-G138, 2008.

19. Matthews PJ, Aziz Q, Facer P, Davis JB, Thompson DG and Anand P: Increased capsaicin receptor TRPV1 nerve fibres in the inflamed human oesophagus. Eur J Gastroenterol Hepatol 16: $897-902,2004$

20. Amadesi S, Nie J, Vergnolle N, Cottrell GS, Grady EF, Trevisani M, Manni C, Geppetti P, McRoberts JA, Ennes H, et al: Protease-activated receptor 2 sensitizes the capsaicin receptor transient receptor potential vanilloid receptor 1 to induce hyperalgesia. J Neurosci 24: 4300-4312, 2004.

21. Yisireyili M, Takeshita K, Hayashi M, Wu H, Uchida Y, Yamamoto K, Kikuchi R, Hao CN, Nakayama T, Cheng XW, et al: Dipeptidyl peptidase-IV inhibitor alogliptin improves stress-induced insulin resistance and prothrombotic state in a murine model. Psychoneuroendocrinology 73: 186-195, 2016.

22. Yisireyili M, Hayashi M, Wu H, Uchida Y, Yamamoto K, Kikuchi R, Shoaib Hamrah M, Nakayama T, Wu Cheng X, Matsushita T, et al: Xanthine oxidase inhibition by febuxostat attenuates stress-induced hyperuricemia, glucose dysmetabolism, and prothrombotic state in mice. Sci Rep 7: 1266, 2017.

23. Li Q, Kong L, Zhang S, Zhong Z, Liu X, Wang J and Kang J: A novel external esophageal perfusion model for reflux-associated respiratory symptoms. Pathobiology 77: 163-168, 2010.

24. Yisireyili M, Uchida Y, Yamamoto K, Nakayama T, Cheng XW, Matsushita T, Nakamura S, Murohara T and Takeshita $K$ : Angiotensin receptor blocker irbesartan reduces stress-induced intestinal inflammation via AT1a signaling and ACE2-dependent mechanism in mice. Brain Behav Immun 69: 167-179, 2018.

25. Livak KJ and Schmittgen TD: Analysis of relative gene expression data using real-time quantitative PCR and the 2(-Delta Delta C(T)) method. Methods 25: 402-408, 2001.

26. Abd El-Rehim DM, Fath El-Bab HK and Kamal EM: Expression of proteinase-activated receptor-2 in the esophageal mucosa of gastroesophageal reflux disease patients: A histomorphologic and immunohistochemical study. Appl Immunohistochem Mol Morphol 23: 646-652, 2015.
27. Seo JS, Park JY, Choi J, Kim TK, Shin JH, Lee JK and Han PL: NADPH oxidase mediates depressive behavior induced by chronic stress in mice. J Neurosci 32: 9690-9699, 2012.

28. Aviello G and Knaus UG: ROS in gastrointestinal inflammation: Rescue or sabotage? Br J Pharmacol 174: 1704-1718, 2017.

29. Peng YL, Liu YN, Lei L, Wang X, Jiang CL and Wang YX: Inducible nitric oxide synthase is involved in the modulation of depressive behaviors induced by unpredictable chronic mild stress. J Neuroinflammation 9: 75, 2012.

30. Caterina MJ, Leffler A, Malmberg AB, Martin WJ, Trafton J, Petersen-Zeitz KR, Koltzenburg M, Basbaum AI and Julius D: Impaired nociception and pain sensation in mice lacking the capsaicin receptor. Science 288: 306-313, 2000.

31. Inci K, Edebo A, Olbe L and Casselbrant A: Expression of protease-activated-receptor 2 (PAR-2) in human esophageal mucosa. Scand J Gastroenterol 44: 664-671, 2009.

32. Wu L, Oshima T, Shan J, Sei H, Tomita T, Ohda Y, Fukui H, Watari $\mathbf{J}$ and Miwa H: PAR-2 activation enhances weak acid-induced ATP release through TRPV1 and ASIC sensitization in human esophageal epithelial cells. Am J Physiol Gastrointest Liver Physiol 309: G695-G702, 2015.

33. Hoogerwerf WA, Zou L, Shenoy M, Sun D, Micci MA, Lee-Hellmich H, Xiao SY, Winston JH and Pasricha PJ: The proteinase-activated receptor 2 is involved in nociception. J Neurosci 21: 9036-9042, 2001.

34. Kirkup AJ, Jiang W, Bunnett NW and Grundy D: Stimulation of proteinase-activated receptor 2 excites jejunal afferent nerves in anaesthetised rats. J Physiol 552: 589-601, 2003.

35. Groschwitz KR, Wu D, Osterfeld H, Ahrens R and Hogan SP: Chymase-mediated intestinal epithelial permeability is regulated by a protease-activating receptor/matrix metalloproteinase-2-dependent mechanism. Am J Physiol Gastrointest Liver Physiol 304: G479-G489, 2013.

36. Enjoji S, Ohama T and Sato K: Regulation of epithelial cell tight junctions by protease-activated receptor 2. J Vet Med Sci 76: 1225-1229, 2014.

37. Ma J, Altomare A, Guarino M, Cicala M, Rieder F, Fiocchi C, Li D, Cao W, Behar J, Biancani P and Harnett KM: HCl-induced and ATP-dependent upregulation of TRPV1 receptor expression and cytokine production by human esophageal epithelial cells. Am J Physiol Gastrointest Liver Physiol 303: G635-G645, 2012. 